\title{
VII. Ogólnopolskie Forum Sądowe
}

W dniach 8 i 9 czerwca 2015 r. odbyło się w Gródku n. Dunajcem w ośrodku rekolekcyjnym Diecezji Tarnowskiej „Arka”, pod patronatem naukowym Rady Prawnej Konferencji Episkopatu Polski, VII. Ogólnopolskie Forum Sądowe - „Kanoniczny proces małżeński dziesięć lat po opublikowaniu Dignitas connubii”.

Konferencja pragnęła nawiązać do słów papieża Franciszka wypowiedzianych dnia 24 stycznia 2015 r. do uczestników Międzynarodowego Kongresu Prawa Kanonicznego zorganizowanego w Rzymie z okazji dziesięciolecia wydania instrukcji procesowej „Dignitas connubii”: „Nie zostały dotychczas zgłębione wszystkie zasoby, które Instrukcja ofiaruje celem przyspieszenia procesu (...), nie można jednak wykluczyć w przyszłości kolejnych interwencji ustawodawczych skierowanych na ten cel".

Gościem konferencji był ks. prof. dr Joaquín Llobell z Rzymu, natomiast okolicznościowe pisemne pozdrowienia uczestnikom spotkania przesłali abp CelestinoMigliore - Nuncjusz Apostolski w Polsce, kard. Stanisław Dziwisz - Metropolita Krakowski oraz abp Wojciech Polak - Prymas Polski.

Konferencję otworzył oraz wprowadził w jej tematykę bp dr hab. Artur G. Miziński - Sekretarz Generalny Konferencji Episkopatu Polski, który w swoim słowie zaznaczył między innymi, że „we współczesnym świecie mamy do czynienia $\mathrm{z}$ wieloma problemami dotyczącymi relacji międzyludzkich. W Kościele wzrasta potrzeba dyskusji i poszukiwania skutecznych działań przede wszystkim w ramach duszpasterstwa rodzin. Jednakże fakt istnienia dużej liczby niesakramentalnych związków osób ochrzczonych domaga się 
podjęcia duszpasterskiej troski również w relacji do tych osób. Dobro duchowe wiernych domaga się dania wiernym możliwości poznania prawdy na temat ważności ich małżeństwa, szczególnie w przypadku jego rozpadu. Mając na uwadze tę kwestię papież Franciszek - obok istniejącej już przy Papieskiej Radzie ds. Tekstów Prawnych komisji zajmującej się reformą procesu małżeńskiego - powołał we wrześniu inną specjalną komisję, mającą na celu przygotowanie norm usprawniających ten proces. Troska papieża zmierza $\mathrm{w}$ kierunku nadania maksymalnej efektywności istniejących procedur w kontekście osób oczekujących przez lata na orzeczenie Kościoła odnośnie do ewentualnej nieważności ich małżeństwa. Ojciec Święty zauważył również, że niektóre procedury są tak uciążliwe, iż wiele osób z nich rezygnuje".

Sesjom w pierwszym dniu przewodniczył ks. dr Maciej Kubala, natomiast w drugim dniu konferencji dr Zofia Orłowska.

Ponadto w czasie konferencji odbyły się dwa niezależne spotkania oficjałów oraz adwokatów kościelnych, którym przewodniczyli odpowiednio ks. dr hab. Leszek Adamowicz, prof. KUL oraz ks. prof. dr hab. Ryszard Sztychmiler z Uniwersytetu Warmińsko-Mazurskiego.

Natomiast porannej koncelebrowanej Mszy św. na początku drugiego dnia konferencji przewodniczył ks. dr Ireneusz Borawski oficjał łomżyński, podczas której okolicznościową oraz wymowną homilię pt. „Posługa sądowa w Kościele” wygłosił ks. dr Waldemar Gałązka - oficjał sandomierski, między innymi pouczając: „Wiele problemów nurtuje nas w pracy sądowej. Musimy je podejmować i stawiać sobie pytania o prawidłowość naszej posługi. Nie można jednak zamknąć się w prowadzonym teraz przeze mnie „rachunku sumienia”, a tym bardziej stać się skrupulatem, któremu strach będzie paraliżował podejmowanie decyzji. Trzeba ufać, że skoro Bóg przez swoich przedstawicieli na ziemi zlecił nam tę posługę, to towarzyszy nam w niej każdego dnia, stoi przy nas, wspomaga nas i oświeca, czeka na naszą prośbę o wsparcie, o światło Ducha Świętego zwłaszcza w sprawach trudnych. Bywa, że przed wyrobieniem sobie zdania na temat trudnej sprawy chce, abyśmy odłożyli decyzję i jeszcze raz ją przemodlili. Zresztą, nie tylko w związku z trudnymi problemami, 
ale też niezależnie od nich często, a może nawet codziennie trzeba nam prosić Go, żeby nas prowadził, oświecał i dawał radość z tej specyficznej służby Jemu w naszych braciach, na tyle, na ile jesteśmy do tego zdolni. Przecież, jak mówi nam dziś święty Paweł, „tym, który umacnia nas (...) w Chrystusie (...) jest Bóg. On też wycisnął na nas pieczęć i zostawił zadatek Ducha w sercach naszych" (2 Kor 1, 21-22). Skoro tak, to ufni w Jego działanie w nas, wracajmy do naszej codziennej pracy w łączności z Nim”.

W czasie siódmego forum sądowego zostały wygłoszone następujące referaty: „La pastoralità del complesso processo canonico matrimoniale: suggerimenti per renderlo più facile e tempestivo" („Duszpasterski aspekt złożoności procesu małżeńskiego: propozycje ułatwienia i przyspieszenia”) - ks. prof. dr Joaquín Llobell, Uniwersytet Papieski św. Krzyża w Rzymie; „Wiara a ważność małżeństwa sakramentalnego: spojrzenie prawno-dowodowe" - ks. prof. dr hab. Grzegorz Leszczyński, UKSW; „Nieważność procesu małżeńskiego ob ius defensionis denegatum - KPK, kan. 1620, n. $7^{\circ}$ (DC, art. 270, n. $7^{\circ}$ )” - ks. prof. dr hab. Tomasz Rozkrut, UPJPII; „Aspekty praktyczne dowodzenia w procesach o nieważność małżeństwa” - ks. prof. dr hab. Ryszard Sztychmiler, UWM; „Zasada salus animarum jako kryterium interpretacyjne obowiązków sędziego i obrońcy węzła małżeńskiego" - dr hab. Marta Greszata-Telusiewicz, prof. KUL; „Niezdolność do małżeństwa z powodu homoseksualizmu w orzecznictwie rotalnym” - ks. dr Jan Słowiński, UAM; „Homoseksualizm w opinii biegłego" - dr n. med. Wojciech Chodorowicz, biegły w zakresie psychologii i seksuologii.

Zarówno w pierwszym jak i drugim dniu sympozjum, wokół problematyki w/w referatów wywiązała się interesująca dyskusja, w szczególności wokół proponowanych zmian w kanonicznym procesie małżeńskim miała miejsce żywa oraz polemiczna dyskusja polskich kanonistów z Profesorem z Rzymu.

Zwyczajowym już elementem forum, budującym wspólnotę tego sympozjum, była tradycyjna „koleżeńska kolacja”, mająca charakter wiejskiej biesiady, w ogrodzie ośrodka goszczącego kanonistów z Polski oraz zza granicy. 
Materiały z konferencji, podobnie jak z poprzednich sądowych spotkań w Gródku nad Dunajcem, zostaną wydane przez „Biblos” Wydawnictwo Diecezji Tarnowskiej.

ks. Tomasz Rozkrut 